\title{
PENDEDERAN IKAN PATIN DI KOLAM OUTDOOR UNTUK MENGHASILKAN BENIH SIAP TEBAR DI WADUK MALAHAYU, BREBES, JAWA TENGAH
}

\author{
Septyan Andriyanto*), Evi Tahapari*), dan Irsyaphiani Insan*) \\ *) Pusat Penelitian dan Pengembangan Perikanan Budidaya \\ Jl. Ragunan 20, Pasar Minggu, Jakarta Selatan 12540 \\ E-mail: septian08@yahoo.com \\ * Balai Penelitian Pemuliaan Ikan \\ Jl. Raya Sukamandi No. 2, Subang 41256
}

\begin{abstract}
ABSTRAK
Kementerian Kelautan dan Perikanan memiliki program berupa industrialisasi perikanan dengan salah satu komoditas unggulannya yaitu ikan patin. Dalam rangka mendukung pengembangan program tersebut, maka dilakukan kegiatan "Pemasyarakatan IPTEK (IPTEKMAS) Pendederan Ikan Patin di Waduk Malahayu, Brebes, Jawa Tengah", yang bertujuan sebagai transfer teknologi pendederan untuk menghasilkan benih ikan patin dengan ukuran yang siap dibesarkan atau siap ditebar sebagai benih restocking di Waduk Malahayu. Tahapan kegiatan IPTEKMAS ini di antaranya pemilihan lokasi, koordinasi dan sosialisasi, pelatihan dan pendampingan teknologi pendederan ikan patin, serta temu lapang dan restocking benih ikan patin di Waduk Malahayu. Kegiatan yang dilakukan dalam pendederan ikan patin meliputi: persiapan kolam pendederan, penebaran benih, pemberian pakan, pengelolaan kualitas air, manajemen kesehatan ikan, dan teknik pemanenan benih. Melalui kegiatan ini dihasilkan benih ikan patin berukuran 4-5 inci atau $10 \mathrm{~g}$, dengan tingkat sintasan benih rata-rata sebesar 98,76\% Manfaat yang diperoleh selain nelayan mampu mendederkan sendiri benih ikan patin sampai ukuran restocking, juga mendukung program restocking di Waduk Malahayu yang berdampak pada peningkatan pendapatan nelayan setempat tanpa merusak lingkungan perairan.
\end{abstract}

KATAKUNCl: pendederan, patin, IPTEKMAS, restocking, Waduk Malahayu

\section{PENDAHULUAN}

Di Indonesia Pangasius sutchi sinonim dengan Pangasius hypophthalmus mempunyai prospek yang baik dalam pemasaran, karena mempunyai nilai ekonomis yang tinggi baik pada tingkat benih sebagai ikan hias maupun pada tingkat dewasa sebagai ikan konsumsi. Sehingga banyaknya permintaan harus dibarengi dengan peningkatan produksi (Hardjamulia et al., 1987). Peningkatan produksi hanya dapat dicapai melalui budidaya perikanan, karena peningkatan produksi melalui penangkapan akan mengganggu kelestarian sumberdaya perikanan. Jenis ikan yang dibudidayakan harus mempertimbangkan ikan yang mempunyai pangsa pasar yang cukup besar, mudah dibudidayakan, serta mempunyai resistensi patologi yang cukup tinggi seperti ikan patin.

Pemeliharaan ikan patin siam (Pangasius hypophthalmus) sampai ukuran 1 inci selama ini masih dilakukan secara indoor dengan tingkat keberhasilan sekitar 50\%60\% Usaha pendederan di kolam outdoor sampai saat ini relatif belum banyak dilakukan (Tahapari et al., 2008). Produksi ikan patin yang dibudidayakan di kolam dari tahun 2005 (21.606 ton) sampai 2010 (104.574 ton) mengalami peningkatan sebesar 82.968 ton (484\%). Produksi di keramba dari tahun 2005 (7.094 ton) sampai 2010 (22.552 ton) meningkat sebesar 15.458 ton (318\%, sedangkan produksi ikan patin yang dibudidayakan di sawah tahun 2005 sampai 2010 meningkat sebesar 143 ton. Produksi ikan patin yang dibudidayakan di jaring apung dari tahun 2005 (3.875 ton) sampai tahun 2010 (20.219 ton) mengalami peningkatan sebanyak 16.344 ton $(522 \%$ (DJPB, 2010).

Dalam pelaksanaan kegiatan restocking yang dilakukan oleh kelompok nelayan "Nila Jaya" di perairan Waduk Malahayu, selama ini masih mengandalkan sumber benih dari luar (hasil budidaya) yang dibeli dari pembenih ikan patin dari luar kawasan Malahayu. Hal ini tentu saja membutuhkan biaya yang tidak sedikit bagi masyarakat nelayan. Dalam rangka mendukung pengembangan program tersebut, maka dilakukan kegiatan "Pemasyarakatan IPTEK Pendederan Ikan Patin di Waduk Malahayu, 
Brebes, Jawa Tengah" dengan harapan untuk ke depannya para nelayan dapat menyediakan benih untuk restocking di Waduk Malahayu dari hasil kegiatan pendederan yang dilakukan secara swadaya oleh para nelayan setempat.

Tujuan pelaksanaan kegiatan Pemasyarakatan IPTEK (IPTEKMAS) ini adalah transfer teknologi pendederan untuk menghasilkan benih ikan patin dengan ukuran yang siap dibesarkan atau siap ditebar sebagai benih restocking di Waduk Malahayu. Transfer teknologi pendederan ini dimaksudkan untuk melengkapi tersedianya teknologi unggul dan efisien secara lengkap dalam meningkatkan produktivitas benih ikan patin di kolam. Rakitan teknologi unggul dalam penyediaan benih yang berkualitas dengan jumlah yang memadai diperlukan untuk meningkatkan produktivitas komoditas yang dipelihara dalam tahap pembesaran baik di kolam budidaya maupun di perairan umum (waduk).

\section{TAHAPAN KEGIATAN}

\section{Pemilihan Lokasi}

Pemilihan lokasi IPTEKMAS dilakukan dalam kawasan pengembangan Balai Benih Ikan (BBI) dan Waduk Malahayu, sebelumnya telah dilakukan kajian kelayakan terhadap sumber air, kondisi wadah/kolam pendederan, dan fasilitas pendukung lainnya untuk kegiatan pendederan ikan patin, serta kesiapan sumberdaya manusia (nelayan) yang akan melakukan kegiatan tersebut.

Balai Benih Ikan Malahayu memiliki luas areal \pm 4 ha terdiri atas: gedung/bangunan sebanyak 6 buah (1 kantor, 1 hatcheri, 1 ruang pertemuan, 1 gudang, dan 2 guest house) dan kolam tembok sebanyak 21 buah (masingmasing berukuran $\pm 1.000 \mathrm{~m}^{2}$ ), sedangkan Waduk Malahayu memiliki luas 620 ha dengan kedalaman ratarata $8 \mathrm{~m}$ dan fluktuasi tinggi muka air 3 m/tahun. Kolam yang dipilih untuk kegiatan pendederan benih ikan patin sebanyak 3 (tiga) buah kolam (C2, C3, dan C4) dan masingmasing berukuran $1.000 \mathrm{~m}^{2}$.

Pertimbangan aspek lokasi juga didukung dengan adanya kesediaan kerja sama pemerintah setempat (Dinas Kelautan dan Perikanan Kabupaten Brebes/BBI Malahayu) dengan Kelompok Nelayan "Nila Jaya” yang beranggotakan sebanyak 200 nelayan dan terbagi dalam 5 sub kelompok.

\section{Koordinasi dan Sosialisasi}

Pelaksanaan kegiatan IPTEKMAS dimulai dari bulan Oktober sampai Desember 2011, yang terdiri atas beberapa tahapan di antaranya: koordinasi awal pelaksanaan IPTEKMAS diperoleh hasil berupa kesepakatan pelaksanaan bersama IPTEKMAS Terpadu;
FGD (koordinasi dengan pemda setempat tentang rencana pelaksanaan IPTEKM AS Terpadu) dengan output diperoleh estimasi kebutuhan teknologi dan ukuran benih restocking; sosialisasi rencana penebaran benih restocking diperoleh output rencana jumlah benih yang akan ditebar; sosialisasi teknologi pendederan untuk restocking dengan output kegiatan pendampingan teknologi pendederan untuk kebutuhan benih restocking; pertemuan dalam rangka persiapan kolam pendederan yang menghasilkan output berupa penerapan SOP untuk persiapan kolam pendederan.

\section{Pelatihan dan Pendampingan Teknologi Pen- dederan Ikan Patin}

Dalam upaya untuk mencapai target keberhasilan pendederan ikan patin yang dilakukan oleh anggota nelayan "Nila Jaya" dan teknisi Balai Benih Ikan (BBI) Malahayu Dinas Kelautan dan Perikanan Kabupaten Brebes. Sebelum pelaksanaan kegiatan pendederan dilakukan, terlebih dahulu diadakan kegiatan pelatihan dan pendampingan secara intensif oleh tim peneliti dari Pusat Penelitian dan Pengembangan Perikanan Budidaya dengan materi yang disampaikan adalah Prosedur Operasional Standar (POS) mengenai "Teknologi Pendederan Ikan Patin Siam (Pangasianodon hypophthalmus) secara outdoor di kolam".

Peserta pelatihan diikuti oleh perwakilan dari 5 sub kelompok nelayan serta teknisi BBI Malahayu. Selain pelatihan dilakukan pula kunjungan lapang/survai kondisi kolam yang akan digunakan untuk pendederan benih ikan patin serta fasilitas pendukung lainnya.

\section{Pendederan Ikan Patin}

Beberapa hal yang harus diperhatikan dalam pendederan ikan patin antara lain: persiapan kolam pendederan, penebaran benih, pemberian pakan, pengelolaan kualitas air, manajemen kesehatan ikan, dan teknik pemanenan benih.

\section{Persiapan Kolam Pendederan}

Dalam suatu kegiatan budidaya (pendederan) ikan, aspek persiapan kolam sebelum penebaran benih ikan merupakan hal yang harus diperhatikan, karena dapat berpengaruh terhadap hasil yang akan diperoleh pada saat panen. Persiapan-persiapan tersebut mencakup beberapa aspek di antaranya: sumber air bebas bahan pencemar; tersedianya saluran air masuk dan keluar; pengangkatan lumpur kolam; pengeringan; pengapuran (dosis $100 \mathrm{~g} / \mathrm{m}^{2}$ ); pengisian air; pemberian saponin (dosis $25 \mathrm{mg} / \mathrm{L}$ ); serta pemupukan menggunakan pupuk kompos dengan dosis 
$100 \mathrm{~g} / \mathrm{m}^{2}$, dan pupuk anorganik dengan dosis urea $6 \mathrm{~g} /$ $\mathrm{m}^{2}$, serta TSP $3 \mathrm{~g} / \mathrm{m}^{2}$.

\section{Penebaran Benih}

Metode yang digunakan untuk penebaran benih di antaranya pengecekan kondisi benih yang baru datang, pengangkutan benih, dan aklimatisasi yaitu memberi kesempatan kepada ikan menyesuaikan diri dengan lingkungan yang baru, dengan tujuan menghindari terjadinya stres pada benih yang akan ditebar di kolam pendederan. Penanganan benih yang akan ditebar dalam kolam pemeliharaan terutama yang baru saja tiba dari perjalanan jauh harus hati-hati. Sesuai dengan pernyataan Arifin et al. (1991) salah aspek penting dari usaha budidaya ikan adalah transportasi ikan hidup tanpa mengakibatkan kematian ikan yang cukup tinggi dan secara ekonomis menguntungkan. Penanganan benih yang akan ditebar ke kolam pendederan meliputi beberapa aspek, yaitu dilakukan secara hati-hati, ukuran benih yang ditebar harus seragam dan cukup kuat, pastikan kondisi kolam sudah siap (ketinggian air stabil, plankton sudah tumbuh), penebaran benih dilakukan pada pagi/sore hari (suhu masih rendah), penebaran secara aklimatisasi. Benih ikan patin yang ditebar berukuran antara $3 / 4-1$ inci sebanyak 600.000 ekor dan dibagi dalam 3 (tiga) kolam (C2, C3, dan C4), masing-masing kolam ditebar sebanyak 200.000 ekor. Proses penebaran benih ditampilkan pada Gambar 1.

\section{Pemberian Pakan}

Salah satu faktor utama yang menentukan keberhasilan pendederan ikan patin adalah pemberian pakan yang sesuai (kualitas dan kuantitas) dengan kebutuhan tumbuh ikan. Patin merupakan ikan omnivora (pemakan segala), artinya patin dapat memanfaatkan pakan alami yang ada di kolam. Benih ikan patin akan tumbuh cepat jika diberi pakan dengan kandungan protein yang memadai ( $32 \%$ $40 \%$. Ariyanto et al. (2008) menyebutkan kepadatan ikan berpengaruh terhadap kondisi lingkungan pemeliharaan. Semakin padat ikan yang dipelihara, pakan yang diberikan juga semakin banyak.

Metode dan waktu pemberian pakan harus disesuaikan dengan kebiasaan ikan makan. Persediaan pakan harus
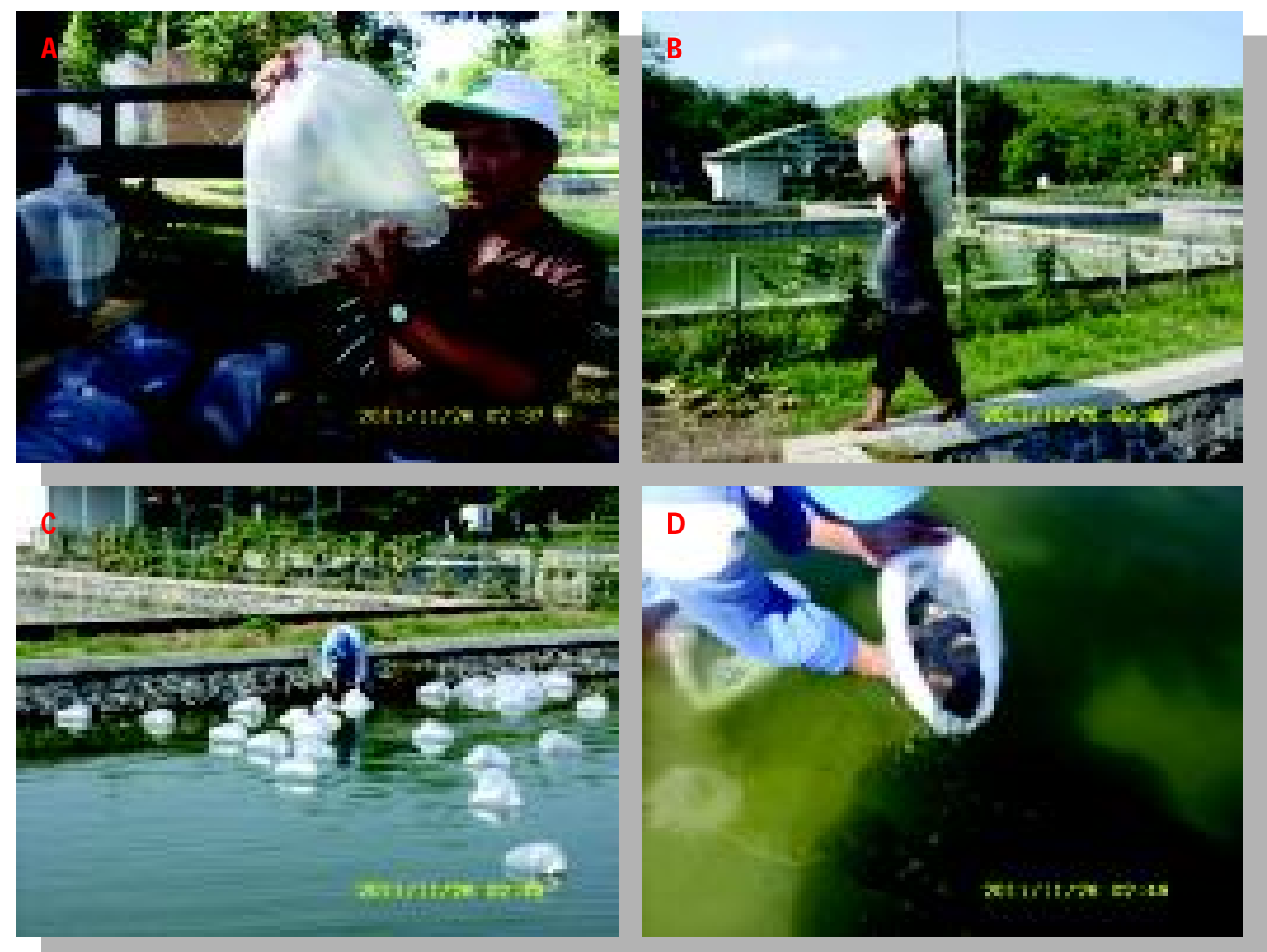

Gambar 1. Proses penebaran benih: (A) pengecekan kondisi benih, (B) pengangkutan benih ke kolam pendederan, (C) aklimatisasi penebaran benih, dan (D) benih keluar setelah aklimatisasi 
tersimpan di tempat dan wadah khusus yang bersih. Sifat fisik pakan harus sesuai dengan kebiasaan makan ikan, pakan tidak mudah hancur dalam air, mempunyai aroma yang dapat menarik dan merangsang nafsu makan. Pakan sebaiknya tidak disimpan terlalu lama, hendaknya tidak lebih dari satu bulan. Pemberian pakan dilakukan tiga kali sehari yaitu pada pagi, siang, dan sore hari. Jumlah pakan yang diberikan dihitung berdasarkan bobot total ikan dari setiap wadah pemeliharaan yang disesuaikan setiap 10 hari. Penentuan dosis pemberian pakan benih ikan patin dilakukan dengan cara menghitung bobot serta panjang badan ikan melalui sampling secara berkala.

Pakan yang diberikan berupa pakan buatan jenis tenggelam, terapung maupun kombinasi keduanya. Ukuran pakan yang diberikan disesuaikan dengan ukuran bukaan mulut ikan. Misalnya untuk pakan tenggelam berbentuk crumble ukuran $\pm 1 \mathrm{~mm}$, kadar protein pakan yang diberikan mulai dari $32 \% 40 \%$ dengan teknik pemberian pakan (Gambar 2) sebagai berikut: 10 hari pertama pemberian pakan dengan kadar protein kasar 40\% 10 hari kedua pemberian pakan dengan kadar protein kasar 35\%38\% dan 10 hari selanjutnya sampai dengan ukuran ikan siap ditebar untuk dibesarkan dengan kadar protein 32\%dengan frekuensi pemberian 3 kali sehari. Jumlah pakan yang diberikan sebanyak 15\%10\% bobot badan/hari. Masa pemeliharaan selama 30-45 hari dengan target panen benih ukuran 3-5 inci. Benih berukuran 3-5 inci siap untuk dipanen dan dipelihara di wadah pembesaran atau ukuran benih untuk restocking.

\section{Pengelolaan Kualitas Air}

Kualitas air yang baik mutlak diperlukan dalam pemeliharaan benih untuk mendapatkan pertumbuhan dan sintasan benih yang tinggi. Agar kualitas air tetap baik, sebaiknya aliran air masuk dan keluar kolam pemeliharaan terjaga dengan baik walaupun aliran air tersebut tidak begitu besar. Lumut dan ganggang yang tumbuh terlalu banyak di kolam pemeliharaan benih ikan harus dihindarkan. Lumut dan ganggang akan sangat mengganggu aktivitas benih patin. Selain itu, juga diperlukan pengecekan dan pengontrolan kualitas air secara rutin yang meliputi: pengecekan kondisi fisik air kolam, pengecekan kualitas air, pembersihan air kolam, dan pembersihan saluran air. Parameter kualitas air yang mutlak harus diperhatikan antara lain suhu, kandungan oksigen terlarut, $\mathrm{pH}$, amoniak $\left(\mathrm{NH}_{3}\right)$, dan nitrit $\left(\mathrm{NO}_{2}\right)$. Kisaran kualitas air hasil pengecekan di kolam pendederan ikan patin terlihat pada Tabel 1.

\section{Manajemen Kesehatan Ikan}

Upaya pencegahan serangan penyakit terhadap benih patin perlu dilakukan agar kondisi ikan tetap sehat yaitu dengan selalu menjaga kualitas air dalam kondisi yang baik. Kondisi air yang baik adalah air yang bebas dari racun terutama yang berasal dari sisa pakan yang mempunyai kadar protein tinggi, di mana apabila tersisa akan cepat membentuk racun amoniak. Upaya lainnya adalah dengan cara meningkatkan nafsu makan ikan. Karena ikan termasuk hewan yang berdarah dingin (poikilothermal) di mana suhu badannya dipengaruhi oleh suhu lingkungan (air) dan proses metabolisme berbanding lurus/sejalan dengan suhu badannya, maka untuk meningkatkan nafsu makan ikan dengan cara meningkatkan suhu airnya. Suhu air yang ideal untuk pemeliharaan ikan patin $28^{\circ} \mathrm{C}-30^{\circ} \mathrm{C}$. Hal lain yang harus diperhatikan untuk menjaga kesehatan ikan adalah kualitas air pemeliharaan yang harus terjaga, dan ini dapat dilakukan salah satunya dengan menjaga ketinggian air kolam minimal $60-80 \mathrm{~cm}$.

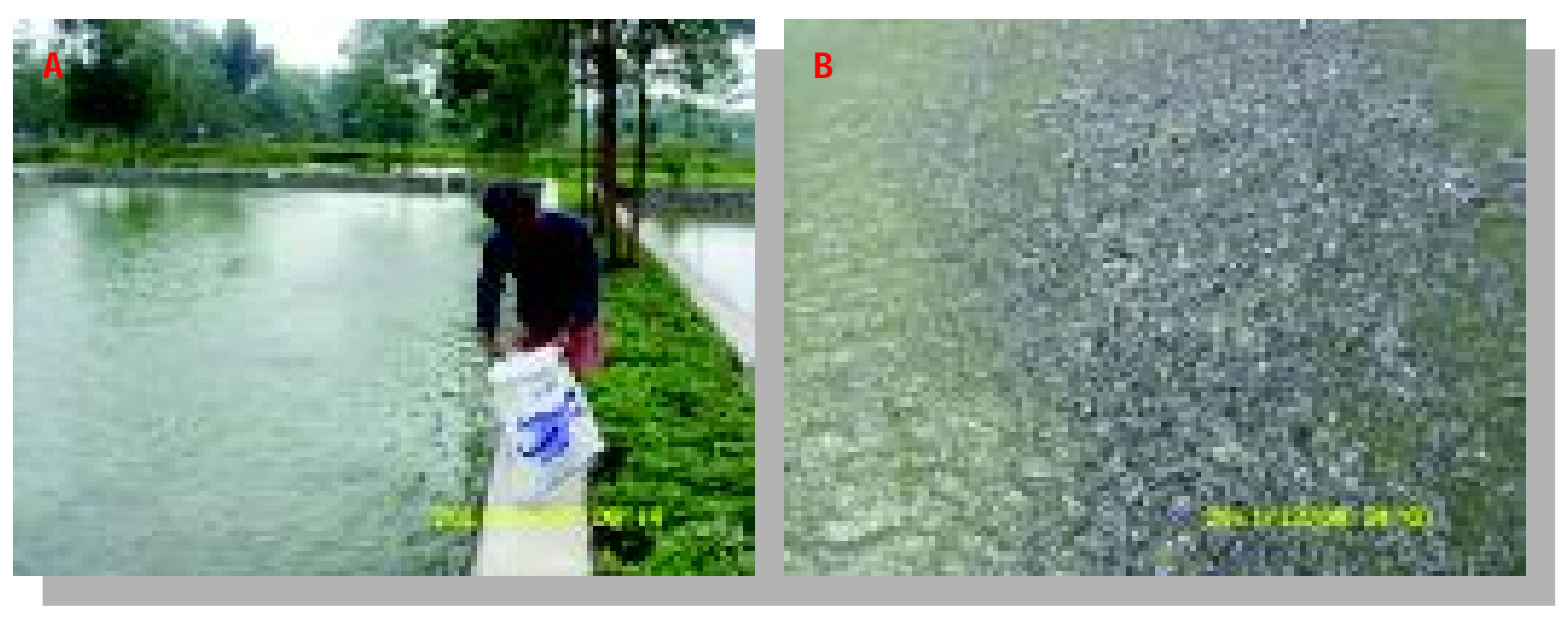

Gambar 2. Teknik pemberian pakan (A) dan kondisi ikan saat pemberian pakan (B) 
Tabel 1. Kisaran kualitas air kolam pendederan ikan patin

\begin{tabular}{ccccccc}
\hline Kolam & Suhu ( $^{\circ} \mathbf{C}$ ) & $\mathbf{0}_{2}$ terlarut $\left.\mathbf{( m g} / \mathbf{L}\right)$ & $\mathbf{p H}$ & Turbiditas (NTU) & Konduktivitas & Keterangan \\
\hline C2 & $30,8-31,3$ & $7,13-7,50$ & 7,6 & 60 & 31,3 & Air kolam surut \\
C3 & $30,9-31,0$ & $7,50-8,03$ & 7,3 & $68-72$ & $30,2-30,5$ & (ketinggian \\
C4 & $31,3-31,5$ & $7,16-7,87$ & 7,3 & $1,01-13,0$ & 31,7 & $\pm 30-50 \mathrm{~cm}$ ) \\
Waduk & $32,3-32,4$ & & $8,2-8,6$ & 2 & $29,6-30,5$ & \\
\hline
\end{tabular}

Catatan: Pemeriksaan di kolam pada pukul 10.00 WIB dan di waduk pada pukul 15.00 WIB

\section{Pemanenan}

Setelah benih ikan patin mencapai ukuran siap dibesarkan (> 3 inci) dapat segera dilakukan pemanenan. Bobot ikan saat pemanenan bervariasi tergantung pada lamanya pemeliharaan, akan tetapi berdasarkan hasil di lapangan rata-rata bobot ikan yang dipanen antara 4-5 inci atau $10 \mathrm{~g}$ dengan tingkat sintasan benih rata-rata sebesar 98,76\% Lama pemeliharaan untuk mencapai ukuran benih siap dibesarkan tergantung pada ukuran ikan yang ditebarkan, target ukuran ikan yang akan dipasarkan dan ukuran yang dikehendaki. Sebelum pemanenan benih dilakukan pemberokan (tidak diberi pakan) selama 24 jam. Pemanenan ikan harus dilakukan dengan cepat dan hati-hati serta diusahakan agar ikan tetap dalam keadaan sehat dan segar. Pada pemeliharaan di kolam tanah, pemanenan melalui beberapa tahapan yaitu pertama dengan menggunakan jaring tarik dan sisanya kolam disurutkan. Peralatan yang digunakan untuk pemanenan harus praktis dan aman bagi ikan. Setelah ikan dipanen kemudian ditampung dalam tempat yang

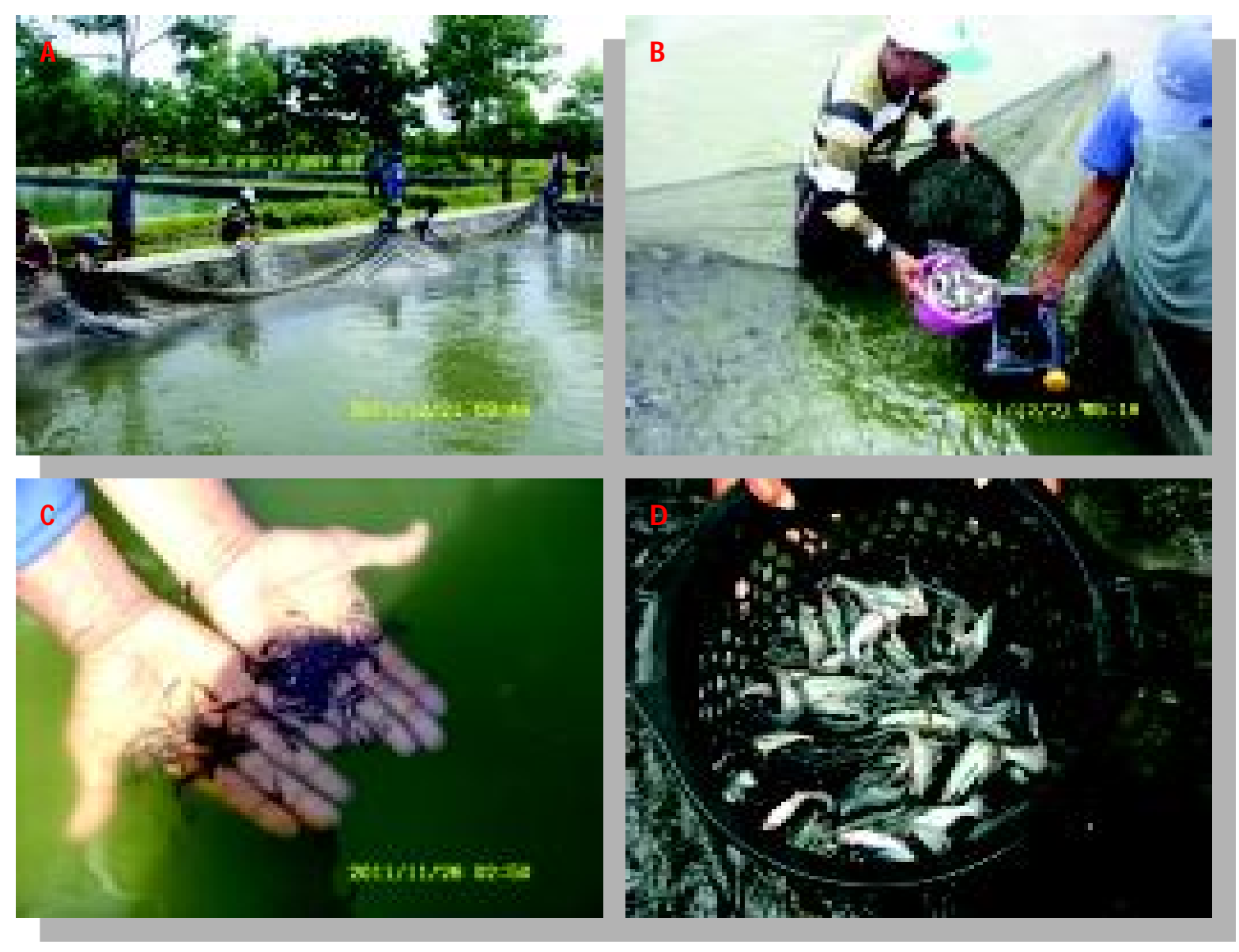

Gambar 3. Peralatan serta tahapan proses pemanenan di antaranya: proses pemanenan dengan jaring tarik (A), pengepakan benih secara terbuka (B), benih saat tebar awal (ukuran 3/4-1 inci) (C), dan benih saat panen (4-5 inci) (D) 
mempunyai aliran air yang baik. Pemberokan harus dilakukan sebelum ikan didistribusikan dalam keadaan hidup. Sebelum pengangkutan ikan harus dikemas dengan persyaratan sistem angkut, sistem pengangkutan ikan dapat dilakukan secara terbuka dengan dilengkapi sistem aerasi dan sistem tertutup dengan menggunakan plastik yang diisi oksigen. Proses pengangkutan ikan dalam keadaan sejuk, keadaan ini umumnya pada pagi atau malam hari. Proses pengangkutan ikan harus mempertimbangkan lamanya waktu perjalanan yang akan ditempuh. Seperti pernyataan Sunarno et al. (1990) selain densitas, lama pengangkutan juga mempengaruhi kualitas air. Semakin lama ikan diangkut, maka oksigen terlarut akan menurun dan meningkatkan buangan metabolit ikan seperti $\mathrm{CO}_{2}$ dan amoniak.

Kegiatan distribusi perlu mempertimbangkan permintaan pasar, harga yang berlaku di pasar. Peralatan serta tahapan proses pemanenan terlihat pada Gambar 3.

\section{KESIMPULAN}

Tingkat sintasan benih rata-rata yang diperoleh sebesar 98,76\%dari jumlah tebar awal sebanyak 600.000 ekor. Setelah pemeliharaan selama 45 hari ukuran mencapai 4-5 inci atau $10 \mathrm{~g}$ dari ukuran awal benih 3/4-1 inci. Melalui kegiatan pendederan bermanfaat dalam mendukung program restocking di Waduk Malahayu yang berdampak pada peningkatan pendapatan nelayan setempat tanpa merusak lingkungan perairan.

\section{DAFTAR ACUAN}

Arifin, Z., Sunarno, M.T.D., \& Kristanto, A.H. 1991. Pengangkutan Benih Patin (Pangasius pangasius) dalam
Kantung Plastik dengan Kepadatan Berbeda. Bulletin Penelitian Perikanan Darat, 10(2): 110-113.

Ariyanto, D., Tahapari, E., \& Gunadi, B. 2008. Optimasi Padat Penebaran Larva Ikan Patin Siam (Pangasius hypophthalmus) pada Pemeliharaan Sistem Intensif. J. Perikanan, X(2): 45-52.

Direktorat Jenderal Perikanan Budidaya. 2011. Statistik Perikanan Budidaya Indonesia 2010. Direktorat Jenderal Perikanan Budidaya, Kementerian Kelautan dan Perikanan, $140 \mathrm{hlm}$.

Hardjamulia, A., Prihadi, T. H., \& Subagyo. 1987. Pengaruh Salinitas Terhadap Pertumbuhan dan Daya Kelangsungan Hidup Benih Ikan Jambal Siam (Pangasius sutchi). Bulletin Penelitian Perikanan Darat, 5(1): 111117.

Kartamihardja, E.S., Purnomo, K., Koeshendrajana, S., \& Prisantoso, B.I. 2011. Panduan Teknis Ko-M anajemen Perikanan Tangkap Berbasis Budidaya (CBF) Di Waduk Malahayu, Kabupaten Brebes, Jawa Tengah. Pusat Penelitian Pengelolaan Perikanan dan Konservasi Sumberdaya Ikan. Badan Penelitian dan Pengembangan Kelautan dan Perikanan, Kementerian Kelautan dan Perikanan, $29 \mathrm{hlm}$.

Sunarno, M.T.D., Kristanto, A.H., \& Arifin, Z. 1990. Pengaruh Lama Pengangkutan Sistem Tertutup Terhadap Kelangsungan Hidup Benih Patin (Pangasius pangasius). Bulletin Penelitian Perikanan Darat, 9(1): 5255.

Tahapari, E., Ariyanto, D., \& Gunadi, B. 2008. Optimasi Pemberian Pakan Buatan pada Pendederan Ikan Patin (Pangasionodon hypophthalmus) di Kolam yang Dipupuk. J. Perikanan, X(1): 45-52. 